\title{
Reef foraminifera as bioindicators of coral reef health in southern South China Sea
}

\author{
Aishah Norashikin Abdul A'ziz ${ }^{1}$, Fatin Izzati Minhat ${ }^{1,2}$, Hui-Juan Pan $^{3}$, Hasrizal Shaari ${ }^{1,2}$, \\ Wan Nurzalia Wan Saelan ${ }^{1,2}$, Nazihah Azmi ${ }^{1}$, Omar Abdul Rahman Abdul Manaf ${ }^{1}$ \& \\ Md Nizam Ismail ${ }^{4}$
}

Pulau Tioman is a famous tourist island off Peninsular Malaysia with beautiful coral reefs. This study aims to assess the health of the coral reefs surrounding Pulau Tioman based on the application of the Foraminifera in Reef Assessment and Monitoring Index (FI). Ten sampling sites around Pulau Tioman were studied with a total of 30 samples. Eight orders, 41 families, 80 genera, and 161 species of benthic foraminifera were identified. The agglutinated type of foraminifera constituted $2-8 \%$ of the total assemblages. Calcareous hyaline and porcelaneous groups represented $79 \%$ and $19 \%$ of the total assemblages, respectively. Symbiont-bearing taxa were the most common foraminifera. The results indicate that most of the sampling sites are conducive for coral reef growth with good recoverability from future stress to the ecosystem. However, several areas with higher coastal development and tourism have reduced water and sediment quality. Therefore, the limit on the number of visitors and tourists should be revised to enable coral growth and health. The FI values in this study showed a positive correlation with good water qualities and a negative correlation with organic matter enrichment. The $\mathrm{Fl}$ is a good measure to assess the health of a coral reef and can be applied to other reef ecosystems around Malaysia.

The coral reef ecosystem is among the most biologically diverse ecosystems in the world that plays a vital role in shaping the balance of environmental processes over the past 200 million years ${ }^{1}$. Coral reefs provide goods and services to marine tropical and subtropical regions ${ }^{2}$. Globally, coral reef ecosystems are threatened or have disappeared due to climate change and human intervention ${ }^{3}$. On a larger scale, elevated sea temperatures and ocean acidification caused by climate change have challenged the natural resilience of tropical reefs ${ }^{4}$. Local stressors from human activities, such as coastal development and pollution, reef predatory practices, and diseases, usually reduce the potential of reef recovery from the ill effects of climate change ${ }^{4-6}$. Because coral reef ecosystems provide various natural environmental services, their ability to survive the global climate anomaly is important. Consequently, understanding the health status of local individual reefs is important to ensure that the coral reef survives and recovers from likely mass mortality events ${ }^{4}$.

Benthic foraminifera can successfully be used to monitor the potential recovery of the reef ecosystem ${ }^{7-9}$. Benthic foraminifera have been proven to be excellent indicators of sediment quality, heavy metal pollution, organic pollution, and water quality ${ }^{10-13}$. Many taxa of Unicellular foraminifera are abundant in reef ecosystems; some of these taxa have similar ecological requirements as those of reef building corals ${ }^{11}$. The development of the Foraminifera in Reef Assessment and Monitoring (FORAM) Index (FI) by Hallock et al. ${ }^{11}$ has enabled continuous monitoring of the health of coral reefs. The FI was developed as a low-cost monitoring tool to indicate whether the quality of water surrounding a reef ecosystem can support reef growth ${ }^{11}$. This index was first applied in the Western Atlantic reef ${ }^{11}$ and has subsequently been applied widely in other regions, including the Great Barrier Reef in Australia ${ }^{7,8}$, reefs in Brazilian waters ${ }^{14}$, and the Saronikos Gulf, Greece ${ }^{15}$. The reliability, simplicity, and cost effectiveness of the FI has made it a suitable indicator for the monitoring of coral reef.

Monitoring the environmental health of the surrounding reef is very important for natural park management authorities to safeguard the coral ecosystems and maintain their ecological importance in Pulau Tioman.

\footnotetext{
${ }^{1}$ Paleoceaonography Research Interest Group (PoRIG), Faculty of Science and Marine Environment, Universiti Malaysia Terengganu, 21030 Kuala Nerus, Terengganu, Malaysia. ${ }^{2}$ Institute of Oceanography and Environment, Universiti Malaysia Terengganu, 21030 Kuala Nerus, Terengganu, Malaysia. ${ }^{3}$ Institute of Earth Sciences, College of Ocean Science and Resource, National Taiwan Ocean University, Keelung, Taiwan. ${ }^{~}$ Fisheries Research Institute, 11960 Batu Maung, Pulau Pinang, Malaysia. ${ }^{\circledR}$ email: fatinminhat@umt.edu.my
} 


\begin{tabular}{|c|c|c|c|c|c|c|c|c|c|c|c|c|}
\hline \multirow[b]{2}{*}{ Station } & \multicolumn{4}{|c|}{ Type of test wall } & \multicolumn{4}{|c|}{ Diversity indices } & \multicolumn{3}{|c|}{ Functional group } & \multirow[b]{2}{*}{$\begin{array}{l}\text { FORAM } \\
\text { index }\end{array}$} \\
\hline & $\begin{array}{l}\begin{array}{l}\text { Water } \\
\text { depth (m) }\end{array} \\
\end{array}$ & $\begin{array}{l}\text { Agglutinated } \\
(\%)\end{array}$ & $\begin{array}{l}\text { Calcareous } \\
\text { hyaline (\%) }\end{array}$ & \begin{tabular}{|l} 
Calcareous \\
porcelaneous \\
$(\%)$
\end{tabular} & $\begin{array}{l}\begin{array}{l}\text { No. of } \\
\text { species (S) }\end{array} \\
\end{array}$ & \begin{tabular}{|l} 
Shannon- \\
Wiener \\
$\left(\mathrm{H}^{\prime}\right)$
\end{tabular} & \begin{tabular}{|l|} 
Pielou's \\
Evenness \\
$\left(\mathrm{J}^{\prime}\right)$
\end{tabular} & $\begin{array}{l}\text { Fisher's } \\
\text { alpha (a) }\end{array}$ & \begin{tabular}{|l|}
$\begin{array}{l}\text { Symbiont- } \\
\text { bearing } \\
(\%)\end{array}$ \\
\end{tabular} & \begin{tabular}{|l|} 
Stress \\
tolerant \\
$(\%)$
\end{tabular} & \begin{tabular}{|l|}
$\begin{array}{l}\text { Others } \\
\text { heterothrophic } \\
\text { taxa(\%) }\end{array}$ \\
\end{tabular} & \\
\hline $\mathrm{A} 1$ & 7 & 1 & 90 & 9 & 17 & 2.36 & 0.63 & 6.43 & 69 & 10 & 21 & 7.5 \\
\hline A2 & 12 & 5 & 84 & 11 & 23 & 2.72 & 0.66 & 11.21 & 62 & 8 & 30 & 6.9 \\
\hline A3 & 13 & 1 & 93 & 7 & 19 & 2.27 & 0.51 & 7.23 & 77 & 9 & 14 & 8.1 \\
\hline B1 & 5 & 0 & 95 & 5 & 11 & 1.74 & 0.52 & 3.26 & 64 & 1 & 5 & 9.3 \\
\hline B2 & 10 & 4 & 94 & 2 & 14 & 2.03 & 0.54 & 4.60 & 94 & 1 & 9 & 9.2 \\
\hline B3 & 15 & 0 & 91 & 9 & 12 & 2.03 & 0.63 & 3.67 & 86 & 1 & 11 & 9.0 \\
\hline $\mathrm{C} 1$ & 5 & 0 & 93 & 7 & 18 & 2.36 & 0.59 & 6.58 & 59 & 13 & 26 & 6.7 \\
\hline $\mathrm{C} 2$ & 14 & 0 & 92 & 7 & 15 & \begin{tabular}{|l|l}
1.91 \\
\end{tabular} & \begin{tabular}{|l|l|}
0.45 \\
\end{tabular} & 5.06 & 55 & 18 & 30 & \begin{tabular}{|l|l|}
6.1 \\
\end{tabular} \\
\hline C3 & 14 & 3 & 84 & 12 & 15 & 2.26 & 0.64 & 5.20 & 50 & 20 & 34 & 5.6 \\
\hline D1 & 6 & 8 & 83 & 10 & 16 & 2.08 & 0.50 & 6.06 & 43 & 4 & 46 & 5.7 \\
\hline D2 & 11 & 2 & 89 & 9 & 17 & 2.33 & \begin{tabular}{|l|}
0.61 \\
\end{tabular} & 6.17 & 62 & 13 & 21 & \begin{tabular}{|l|l}
7.1 \\
\end{tabular} \\
\hline D3 & 15 & 3 & 90 & 7 & 16 & 2.14 & \begin{tabular}{|l|l|}
0.53 \\
\end{tabular} & 5.43 & 83 & 3 & 17 & \begin{tabular}{|l|l}
8.4 \\
\end{tabular} \\
\hline E1 & 5 & 1 & 89 & 10 & 20 & 2.34 & 0.52 & 7.82 & 84 & 4 & 16 & \begin{tabular}{|l|}
8.4 \\
\end{tabular} \\
\hline E2 & 11 & 0 & 90 & 10 & 20 & 2.62 & 0.68 & 7.92 & 71 & 5 & 21 & \begin{tabular}{|l|}
7.8 \\
\end{tabular} \\
\hline E3 & 18 & 2 & 71 & 27 & 24 & 2.95 & \begin{tabular}{|l|}
0.79 \\
\end{tabular} & \begin{tabular}{|l|l}
11.13 \\
\end{tabular} & 14 & 22 & 58 & 3.0 \\
\hline F1 & 5 & 1 & 74 & 25 & 17 & 2.10 & 0.48 & 6.24 & 17 & 51 & 37 & 2.8 \\
\hline F2 & 16 & 2 & 63 & 35 & 20 & 2.54 & \begin{tabular}{|l|}
0.63 \\
\end{tabular} & 8.19 & 29 & 24 & 47 & 4.1 \\
\hline F3 & 18 & 2 & 90 & 8 & 12 & 2.00 & 0.62 & 3.65 & 57 & 21 & 18 & 6.6 \\
\hline G1 & 5 & 8 & 69 & 23 & 23 & 2.69 & 0.64 & 9.91 & 24 & 27 & 52 & 3.6 \\
\hline G2 & 11 & 8 & 72 & 20 & 19 & 2.21 & 0.48 & 7.23 & 47 & 20 & 30 & 5.7 \\
\hline G3 & 18 & 0 & 89 & 11 & 14 & 1.90 & \begin{tabular}{|l|l|}
0.48 \\
\end{tabular} & 4.51 & 84 & 5 & 13 & \begin{tabular}{|l|}
8.5 \\
\end{tabular} \\
\hline $\mathrm{H} 1$ & 5 & 3 & 82 & 15 & 23 & 2.56 & 0.56 & \begin{tabular}{|l|}
10.71 \\
\end{tabular} & 57 & 10 & 32 & 6.5 \\
\hline $\mathrm{H} 2$ & 7 & 1 & 93 & 6 & 17 & 1.83 & 0.37 & 6.03 & 91 & 1 & 14 & \begin{tabular}{|l|}
8.8 \\
\end{tabular} \\
\hline $\mathrm{H} 3$ & 7 & 1 & 95 & 4 & 15 & 1.83 & \begin{tabular}{|l|}
0.41 \\
\end{tabular} & 5.06 & 73 & 3 & 11 & \begin{tabular}{|l|}
8.7 \\
\end{tabular} \\
\hline I1 & 6 & 2 & \begin{tabular}{|l|}
85 \\
\end{tabular} & 13 & 22 & 2.63 & \begin{tabular}{|l|}
0.63 \\
\end{tabular} & 9.28 & 71 & 7 & 21 & \begin{tabular}{|l|}
7.6 \\
\end{tabular} \\
\hline I2 & 8 & 0 & 84 & 16 & 21 & 2.60 & 0.64 & 8.79 & 65 & 11 & 32 & \begin{tabular}{|l|}
6.7 \\
\end{tabular} \\
\hline I3 & 10 & 1 & 94 & 5 & 19 & 2.52 & 0.65 & 7.14 & 73 & 13 & 13 & \begin{tabular}{|l|}
7.8 \\
\end{tabular} \\
\hline $\mathrm{J} 1$ & 5 & 0 & 89 & 10 & 18 & 2.26 & \begin{tabular}{|l|}
0.53 \\
\end{tabular} & 7.03 & 69 & 10 & 26 & \begin{tabular}{|l|}
7.2 \\
\end{tabular} \\
\hline $\mathrm{J} 2$ & 9 & 0 & 97 & 3 & 15 & 1.83 & 0.42 & 5.06 & 85 & 6 & 14 & \begin{tabular}{|l|}
8.4 \\
\end{tabular} \\
\hline $\mathrm{J} 3$ & 13 & 0 & 89 & 11 & 25 & 2.64 & \begin{tabular}{|l|}
0.56 \\
\end{tabular} & \begin{tabular}{|l|l}
10.98 \\
\end{tabular} & 71 & 11 & 21 & \begin{tabular}{|l|l}
7.4 \\
\end{tabular} \\
\hline
\end{tabular}

Table 1. Benthic foraminifera distribution in Pulau Tioman presented in type of test wall (agglutinated, calcareous hyaline and calcareous porcelaneous), diversity indices (number of species (S), the number specimen collected (N), Pielou's eveness (J'), Fisher's alpha $(\alpha)$ and Shannon-wiener (H') indices), functional groups and calculated FORAM index value.

This study aims to assess and monitor the health of the reef environment surrounding the Pulau Tioman island based on the application of the FI.

\section{Results}

Foraminiferal assemblages, functional groups, and FORAM index. A total of 8 orders, 41 families, 80 genera, and 161 species of benthic foraminifera were identified around Pulau Tioman. The most dominant species was Amphistegina lessonii (average of 22\%) and the least dominant species (<4\%) were Bolivina vadescens, Elphidium neosimplex, Heterolepa dutemplei, Heterolepa subhaidingerii, Mikrobelodontos bradyi, Milliolinella suborbicularis, Operculina discoidalis, Parahourinoides fragillissimus, Quinqueloculina incisa, Quinqueloculina sulcata, Triloculinella bertheliniana, and Triloculinella parisa. Overall, the agglutinated foraminifera contributed $2-8 \%$ of the total foraminifera assemblages in Pulau Tioman. Calcareous hyaline and calcareous porcelaneous groups represent on average $79 \%$ and $19 \%$ of the total assemblages, respectively (Table 1). A majority of the species that made up the calcareous hyaline group were larger benthic foraminifera from the Amphistegenidae, Calcarinidae, and Nummulitidae families. As for the porcelaneous species, Miliolidae is the most commonly recorded family. The highest number of species was recorded at station J3 $(S=25)$ while the lowest number of species $(\mathrm{S}=12)$ was at station $\mathrm{F}$. The Shannon-Wiener $\left(\mathrm{H}^{\prime}\right)$ diversity index values around Pulau Tioman were $1.8-3.0$. The species evenness $\left(J^{\prime}\right)$ values were $0.37-0.79$.

Based on the functional groups, the symbiont-bearing taxa, accounting for $63 \%$ of the occurrences, were the most common foraminifera found in almost all stations (Table 1). The symbiont-bearing taxa identified included Amphistegina, Assilina, Calcarina, Coscinospira, Dendritina, Euthymonaca, Heterostegina, Nummulites, Operculina, Pararotalia, Parasorites, Peneroplis, Sorites, and Spirolina (Fig. 1). The abundant stress-tolerant genera, 


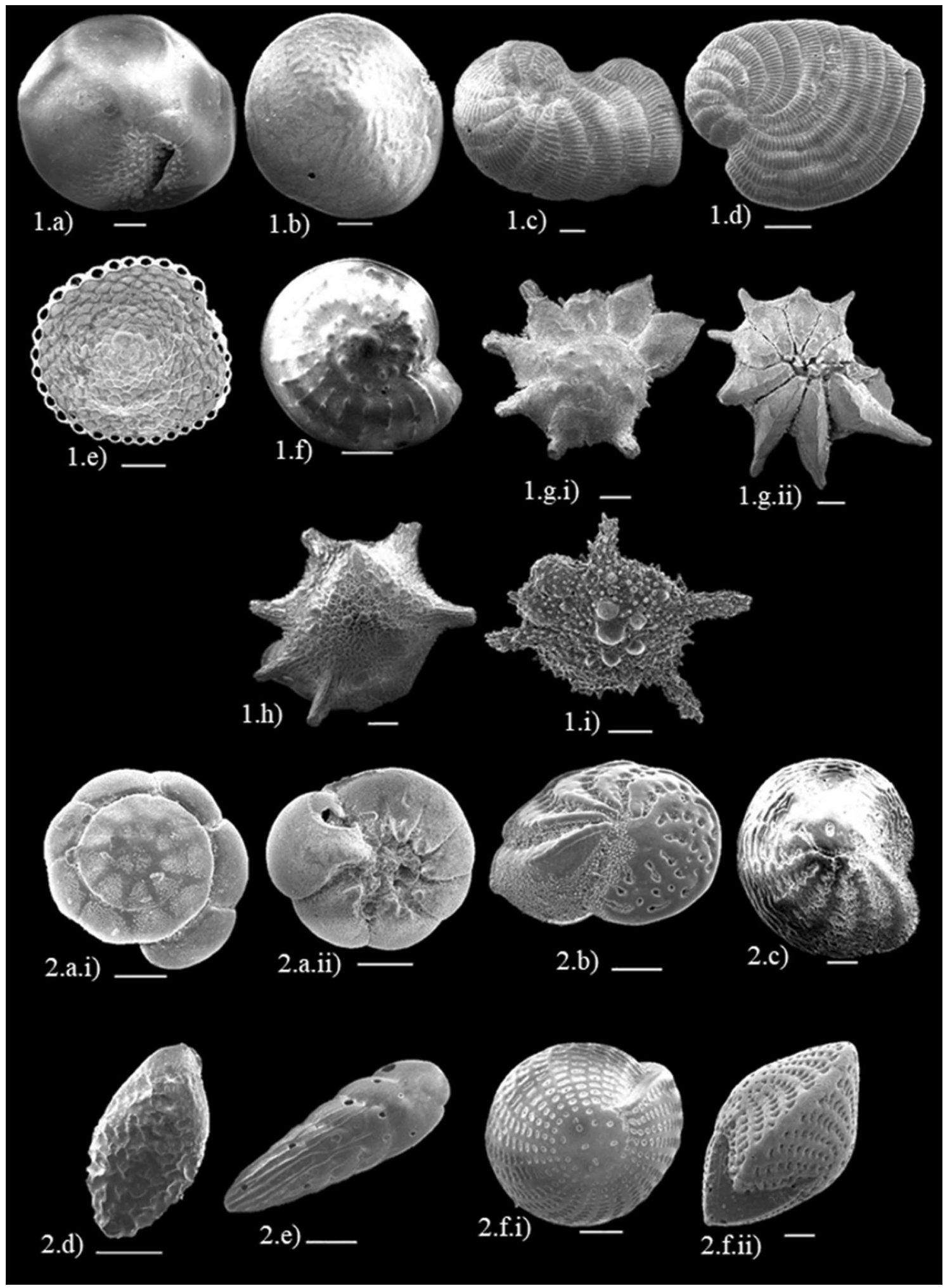

Figure 1. Scanning Electron Micrographs (SEM) of symbiont-bearing genus that possess relatively similar ecological needs as coral reefs. 1.a) Amphistegina lessonii $(100 \mu \mathrm{m} \times 110)$; 1.b) Amphistegina papillosa $(100 \mu \mathrm{m} \times 130)$; 1.c) Peneroplis pertusus $(100 \mu \mathrm{m} \times 100)$; 1.d) Peneroplis planatus $(200 \mu \mathrm{m} \times 90)$; 1.e) Sorites orbiculus $(200 \mu \mathrm{m} \times 80)$; 1.f) Asillina ammonoides $(500 \mu \mathrm{m} \times 43)$; 1.g.i) Lateral side: Pararotalia domatayi $(100 \mu \mathrm{m} \times 110)$; 1.g.ii) Umbilical side: Pararotalia domatayi $(100 \mu \mathrm{m} \times 100)$; 1.h) Calcarina gaudichaudii $(200 \mu \mathrm{m} \times 55)$; 1.i) Calcarina hispida $(200 \mu \mathrm{m} \times 80)$ and Scanning Electron Micrographs (SEM) of opportunist taxa (stress-tolerant)which are more resilient towards ecological changes 2.a.i) Lateral side: Ammonia tepida $(100 \mu \mathrm{m} \times 200)$; 2.a.ii) Umbilical side: $(100 \mu \mathrm{m} \times 220)$; 2.b) Elphidium crispum $(100 \mu \mathrm{m} \times 160)$; 2.c) Parrelina hispidula $(100 \mu \mathrm{m} \times 120)$; 2.d $)$ Bolivina vadescens $(100 \mu \mathrm{m} \times 250)$; 2.e) Bolivina sabahensis $(100 \mu \mathrm{m} \times 220)$; 2.f.i) Lateral side: Cellanthus craticulatus $(200 \mu \mathrm{m} \times 90)$; 2.f.ii) Edge side: Cellanthus craticulatus $(100 \mu \mathrm{m} \times 120)$. 


\begin{tabular}{|l|l|}
\hline FI value & Interpretation \\
\hline$>4$ & Environment conducive to reef growth \\
\hline $2-4$ & Environment marginal for reef growth and unsuitable for recovery \\
\hline$<2$ & Stressed condition and unsuitable for reef growth \\
\hline
\end{tabular}

Table 2. The values and interpretation of FORAM index $(\mathrm{FI})^{11}$.

\begin{tabular}{|c|c|c|c|c|c|c|}
\hline \multirow[b]{2}{*}{ Stations } & \multicolumn{5}{|l|}{ Grain size (\%) } & \multirow[b]{2}{*}{$\begin{array}{l}\text { Organic matter } \\
(\%)\end{array}$} \\
\hline & $\begin{array}{l}\text { Coarse sand } \\
(500 \mu \mathrm{m})\end{array}$ & $\begin{array}{l}\text { Medium sand } \\
(250 \mu \mathrm{m})\end{array}$ & Fine sand $(125 \mu \mathrm{m})$ & $\begin{array}{l}\text { Very fine sand } \\
(63 \mu \mathrm{m})\end{array}$ & $\operatorname{Mud}(<63 \mu \mathrm{m})$ & \\
\hline $\mathrm{A} 1$ & 6.36 & 56.57 & \begin{tabular}{|l|l}
34.28 \\
\end{tabular} & 2.35 & 0.43 & 2.96 \\
\hline A2 & 18.97 & 46.00 & 31.35 & 3.34 & 0.34 & 3.21 \\
\hline A3 & 12.57 & 46.64 & 37.12 & 3.29 & 0.39 & 3.06 \\
\hline $\mathrm{B} 1$ & 98.81 & 0.93 & 0.13 & 0.09 & 0.04 & 3.45 \\
\hline $\mathrm{B} 2$ & 69.48 & 23.53 & 4.95 & 1.62 & 0.43 & 3.74 \\
\hline B3 & 98.95 & 0.71 & 0.19 & 0.12 & 0.03 & 3.22 \\
\hline $\mathrm{C} 1$ & 44.89 & 42.47 & 10.73 & 1.61 & 0.30 & 1.31 \\
\hline $\mathrm{C} 2$ & 73.51 & 16.30 & 9.72 & 0.15 & 0.32 & 1.82 \\
\hline $\mathrm{C} 3$ & 28.12 & 47.69 & 21.60 & 2.08 & 0.51 & 2.14 \\
\hline D1 & 93.21 & 5.55 & 0.94 & 0.21 & 0.09 & 3.26 \\
\hline $\mathrm{D} 2$ & 57.75 & 23.45 & 16.50 & 1.72 & 0.59 & 3.52 \\
\hline D3 & 85.26 & 12.33 & 2.11 & 0.20 & 0.10 & 3.45 \\
\hline E1 & 82.66 & 13.70 & 2.76 & 0.55 & 0.33 & 3.35 \\
\hline E2 & 39.10 & 20.34 & 24.54 & 11.91 & 4.12 & 3.75 \\
\hline E3 & 77.80 & 10.00 & 6.30 & 5.43 & 0.47 & 5.89 \\
\hline F1 & 87.05 & 3.61 & 3.37 & 5.84 & 0.13 & 2.19 \\
\hline F2 & 7.05 & 10.35 & 44.63 & 28.70 & 9.27 & 3.58 \\
\hline F3 & 32.14 & 21.48 & 36.02 & 5.91 & 4.46 & 4.13 \\
\hline G1 & 90.02 & 9.30 & 0.58 & 0.09 & 0.01 & 3.58 \\
\hline G2 & 87.30 & 9.22 & 1.29 & 0.18 & 2.01 & 3.51 \\
\hline G3 & 33.76 & 34.48 & 29.31 & 2.19 & 0.26 & 3.28 \\
\hline H1 & 51.91 & 20.20 & 20.17 & 6.74 & 0.97 & 3.70 \\
\hline $\mathrm{H} 2$ & 68.99 & 16.47 & 10.15 & 3.42 & 0.96 & 3.50 \\
\hline H3 & 90.04 & 7.60 & 1.70 & 0.42 & 0.24 & 3.75 \\
\hline I1 & 36.67 & 9.09 & 50.23 & 0.02 & 3.99 & 3.80 \\
\hline I2 & 23.76 & 4.85 & 62.46 & 0.18 & 8.75 & 3.29 \\
\hline $\mathrm{I} 3$ & 1.52 & 17.79 & 68.07 & 12.56 & 0.07 & 2.97 \\
\hline $\mathrm{J1}$ & 3.50 & 42.23 & 49.68 & 4.55 & 0.03 & 3.75 \\
\hline $\mathrm{J} 2$ & 49.52 & 46.91 & 3.26 & 0.27 & 0.04 & 3.48 \\
\hline $\mathrm{J3}$ & 5.63 & 28.25 & 47.97 & 18.09 & 0.06 & 3.91 \\
\hline
\end{tabular}

Table 3. The composition of sediment grain size and organic matter around Pulau Tioman.

accounting for 12\%, included Ammonia, Bolivina, Cellanthus, Elphidium, Pararotalia, and Rotalia (Fig. 1). The remaining $25 \%$ of the occurrences were contributed by other smaller heterotrophic taxa. An extremely high dominance of the symbiont-bearing group was recorded at station B2 (Kampung Mukut) at a water depth of $10.4 \mathrm{~m}$. The stress-tolerant taxa, in contrast, were dominant at station F1, which is situated close to the Marine Park Centre and jetty.

The FI values from this study varied between 2.8 and 9.2, with most sites around Pulau Tioman representing a conducive environment for reef growth and recovery (FI > 5) (Table 2). However, three stations namely F1, E3, and G1 that have FI values of 2.8, 3.0, and 3.6, respectively, indicated a marginal environment for reef growth and unsuitable conditions for reef recovery.

Sediment characteristics and environmental condition of Pulau Tioman. Most of the sediments in the study area can be classified as sandy with coarse- to medium-grained sand dominating the grain size percentages (Table 3). The study area near Kampung Mukut (B1-B3), where a fishing village is located, has coarser sediment. The study site in Batu Mambang (J1-J3) is dominated by finer sediment. The average percentage of organic matter was $3.35 \pm 0.08 \%$ with a range of $1.31-5.89 \%$ (Table 3 ). The highest organic matter content was 


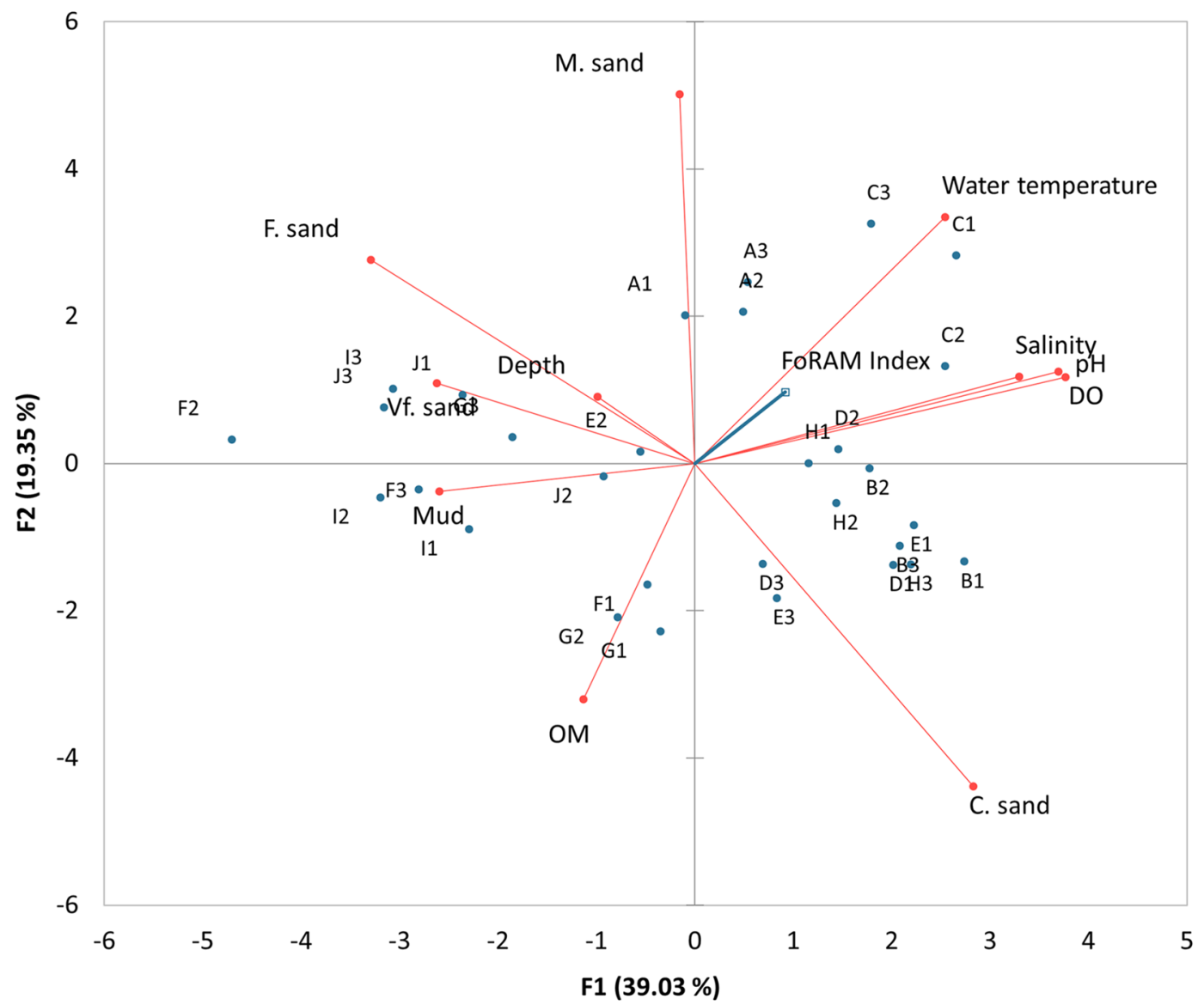

Figure 2. Principal component analysis (PCA) of sediment and water quality and FI data from study area around Pulau Tioman. The variation explained by both axes 1 and 2 is $58.38 \%$. OM-organic matter; C. sandcoarse sand; DO- Dissolved oxygen; M. sand- Medium sand; F. sand- Fine sand; Vf, sand- Very fine sand.

recorded at E3 in the vicinity of Tekek Bay, a famous tourist site for snorkeling and diving. The lowest organic matter content was documented in Gelaber (C1), a sheltered headland that receives fewer tourists.

The average bottom water temperature around Pulau Tioman was $29^{\circ} \mathrm{C}$ with salinity of 33 PSU. The concentration of dissolved oxygen (DO) varied between 4.5 and $6.9 \mathrm{mg} / \mathrm{L}$ with the highest amount of DO recorded at B1 (Kampung Mukut). Meanwhile the water $\mathrm{pH}$ recorded was between 8.1 and 8.7.

Statistical analysis of benthic foraminiferal assemblages. The first and second axes of the Principal Component Analysis (PCA) explained $58.38 \%$ of the variations between the water quality and sediment quality variables (Fig. 2). In addition, the supplementary variables for the FI values indicated a positive correlation between these values and the dissolved oxygen, $\mathrm{pH}$, salinity, and water temperature. Meanwhile, the FI values showed a negative correlation with organic matter, fine sand particles, and the mud composition.

The Monte Carlo permutation test showed that the foraminifera species are linearly related to the water quality and sediment quality data $(p<0.05)$. The axis- 1 of Canonical Correspondence Analysis (CCA) explained $29.1 \%$ of the variance between the species and environmental variables (eigenvalue: 0.29 ) and axis-2 explained 21.8\% (eigenvalue: 0.22 ; Fig. 3). Cluster analysis was conducted to determine the similarities between all the sampling sites based on the number of foraminifera species found around Pulau Tioman. The Q-mode analysis revealed four major groups of benthic foraminiferal assemblages: Group A, Group B, Group C, and Group D (Fig. 4). Group A consisted of two stations (Stations F3 and G3). The foraminiferal assemblages in this group were characterized by a high average abundance of Nummulites venosus (31\%) and Assilina ammonoides (22\%). Group B consisted of Stations E3, F2, G1, and F1. The species that dominated the assemblages in this group was Ammonia tepida with an average relative abundance of $17 \%$. Group C consisted of Stations D1, H2, and H3, and was dominated by Calcarina gaudichaudii (34\%) and Amphistegina lessoni (23\%). Group D consisted of the remaining 21 stations (Stations A1, A2, A3, B1, B2, B3, C1, C2, C3, D2, D3, E1, E2, G2, H1, I1, I2, I3, J1, J2, and J3). The common species identified for the Group D area were Amphistegina lessoni (27\%) and Amphistegina papillosa (8\%). 


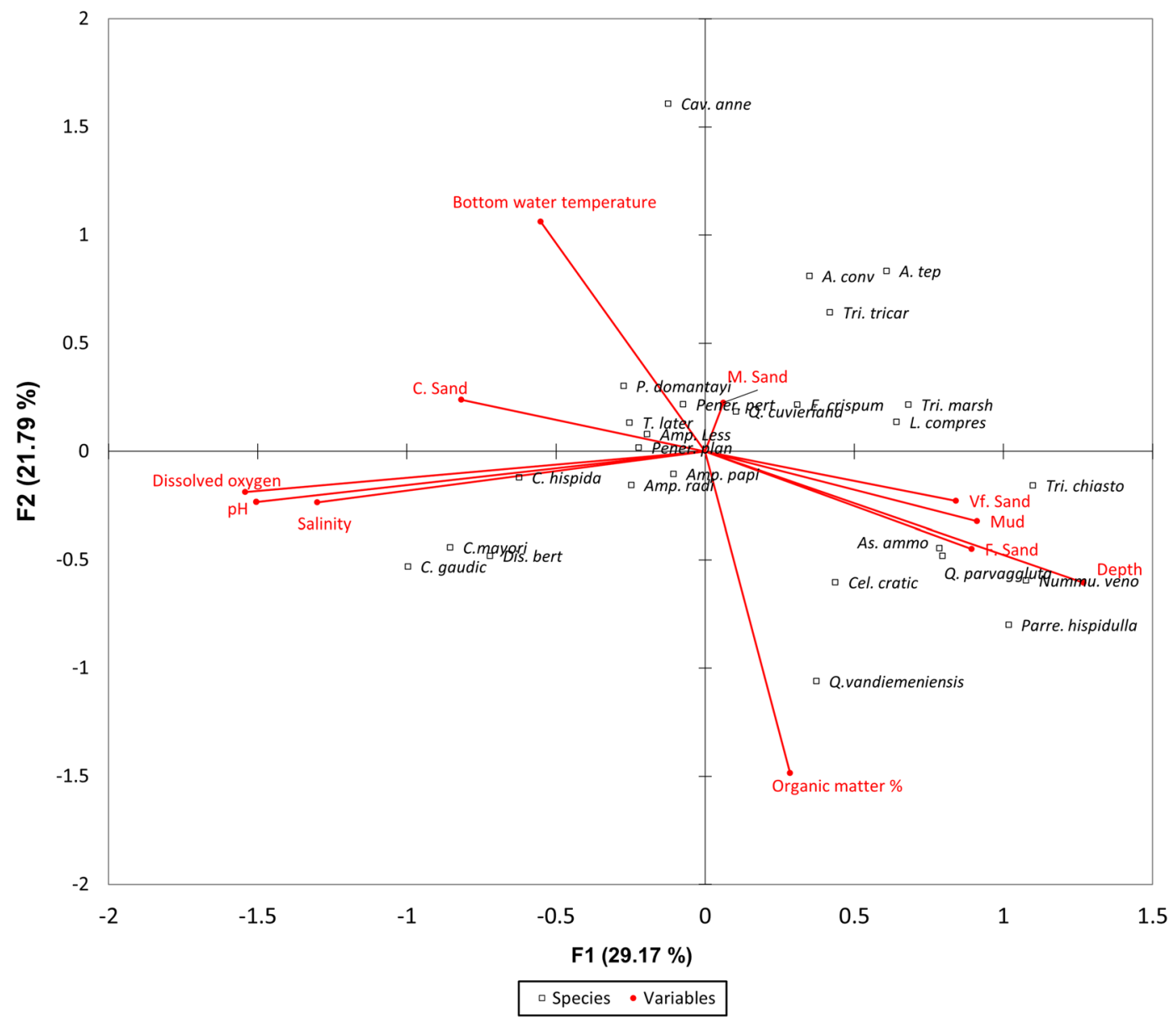

Figure 3. Species-environmental biplot based on Canonical Correspondence Analysis (CCA) of data collected from Pulau Tioman. The total variance of both axes 1 and 2 is (50.96\%). (OM-organic matter; C. sand-coarse sand; DO- Dissolved oxygen; M. sand- Medium sand; F. sand- Fine sand; Vf, sand- Very fine sand) (A. tep=Ammonia tepida; Amp. less =Amphistegina lessoni; Amp. papi=Amphistegina papillosa; Amp. radi=Amphistegina radiata; As. ammo=Assilina ammonoides; C. gaudic=Calcarina gaudichaudii; C. hispida = Calcarina hispida; C. mayori=Calcarina mayori; Cav. Anne = Cavarotalia annectens; Cel. cratic $=$ Cellanthus craticulatus; Dis. bert $=$ Discorbinella bertheloti; E. crispum =Elphidium crispum; $L$. compres = Lachlanella compressiostoma; Nummu. veno = Nummulites venosus; . domantayi = Pararotalia domantayi; Pener. hispidulla = Parrelina hispidulla; Pener. pert $=$ Peneroplis pertusus; Pener. plan $=$ Peneroplis planatus; $Q$. vandiemeniensis $=Q u i n q u e l o c u l i n a$ vandiemeniensis; $Q$. cuvieriana $=$ Quinqueloculina cuvieriana; $Q$. parvaggluta $=$ Quinqueloculina parvaggluta $;$ T. later = Textularia lateralis; Tri. marsh = Triloculina marshallana; Tri. tricar $=$ Triloculina tricarinata; Tri. chiasto $=$ Triloculinella chiastocytis).

\section{Discussion}

Foraminiferal assemblages in Pulau Tioman. The foraminifera assemblages in Pulau Tioman are dominated by rotaliid genera, such as Amphistegina, Calcarina, Operculina, and Peneroplis, with most species having a symbiotic relationship with diatom or algae (Appendix 1), which is similar to worldwide reef foraminifera distributions ${ }^{16-18}$. The foraminifera diversity around Pulau Tioman is slightly higher $\left(\mathrm{H}^{\prime}=1.8-3.0\right)$ than those reported from the fringing reef environment in Brazil ${ }^{19}$. Amphistegina lessoni and Calcarina gaudichaudii, which are among the most widespread species found in Indo-Pacific waters ${ }^{17}$, are highly abundant and common in Pulau Tioman. Amphistegina lessoni, for instance, occurs at all stations around Pulau Tioman, except in F3 (Mesoh), where conditions of high water depths $(>18 \mathrm{~m}$ ), algal distribution, and turbidity exist, which may restrict their presence ${ }^{20}$. Despite relatively lower abundances (4-55\%) compared to that reported in the study on the northern atoll in the South China Sea ${ }^{21}$, the calcareous porcelaneous group (Triloculina, Quinqueloculina, and Lachlanella) contributed to $>50 \%$ of the total foraminiferal assemblage in Pulau Tioman. In Mesoh, where the water depth was $>15 \mathrm{~m}$ and slightly murky, there was a significant increase in porcelaneous representatives, such as Lachlanella compressiostoma (35\%), Triloculina tricarinata (23\%), and Triloculinella chiastocytis (21\%). This finding supports the observations reported in Uthicke et al. ${ }^{8}$ in the Great Barrier Reef, where a high abundance of miliolids was recorded in turbid waters. Triloculina was common in the Dongsha Atoll in the northern South China Sea, but their abundance was recorded to be $<20 \%{ }^{21}$. 


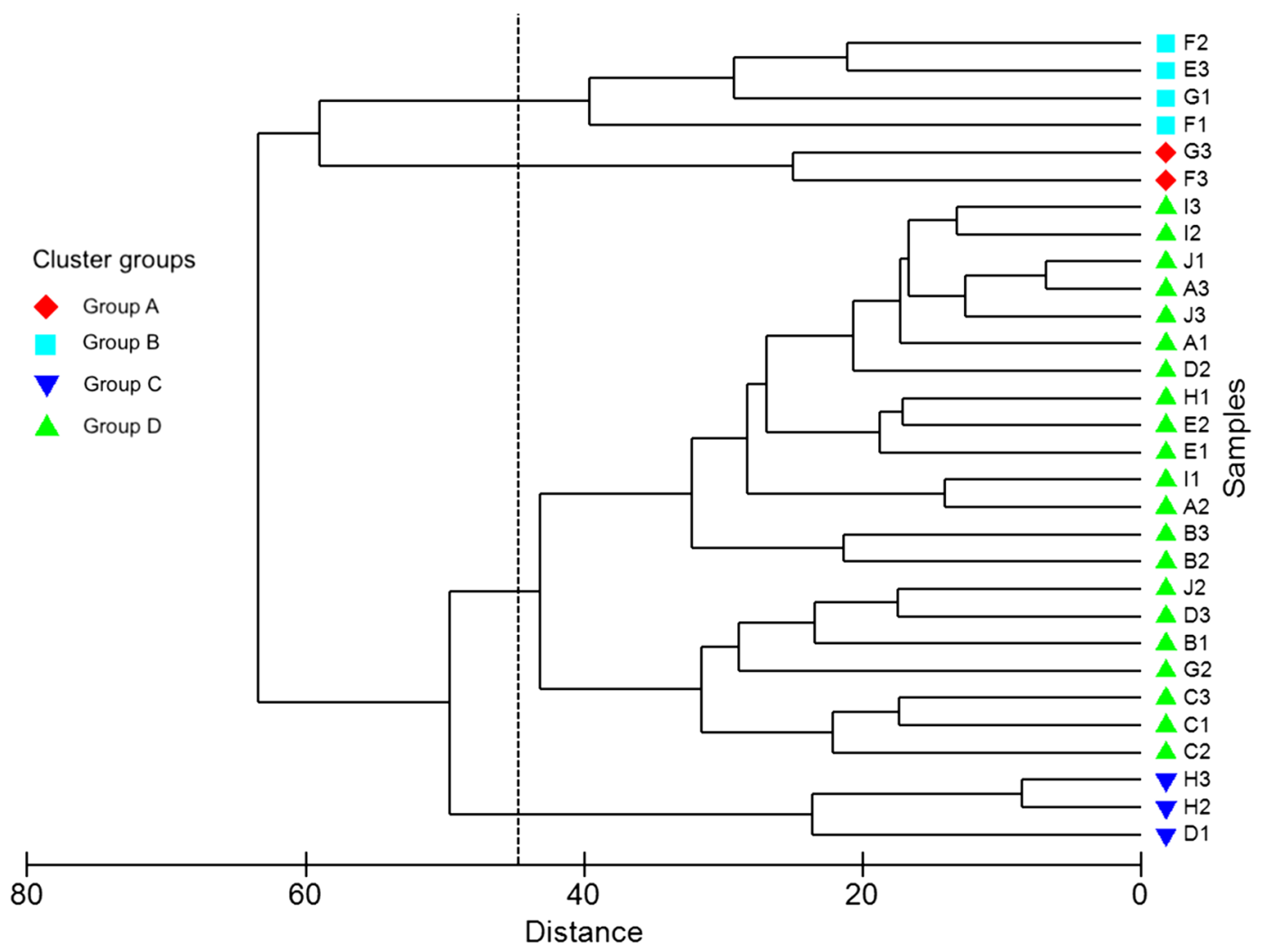

Figure 4. Dendogram produced by cluster analysis based on the complete linkage of benthic foraminiferal assemblages around Pulau Tioman. The stations in Pulau Tioman are divided into four groups (i.e., Group A, $\mathbf{B}, \mathbf{C}$ and $\mathbf{D}$ ) represented by the symbols are based on the distribution of benthic foraminifera assemblages. The distance represents Euclidean distance.

Amphistegina and Calcarina are common in reef environments worldwide ${ }^{22,23}$, especially in Southeast Asia $^{9,24,25}$. Most living Amphistegina can be found attached to reef substrates, with less of a presence in sediment, and usually occur in high abundance in coral reef environments ${ }^{9}$. Owing to their ecological requirements and distribution, foraminifera assemblages are among the best candidates to monitor reef health. Opportunistic taxa, especially Ammonia, Elphidium, and Bolivina, are among those that are tolerant to environmental variations ${ }^{11,13}$. Hence, typically polluted marine conditions, with organic matter enrichment and reduced dissolved oxygen, allow these groups to opportunistically increase in abundance ${ }^{15}$.

In addition, the CCA indicated that environmental variables, such as the concentration of dissolved oxygen $(\mathrm{mg} / \mathrm{L}), \mathrm{pH}$, salinity, and organic matter composition, had the most significant effect on the distribution of benthic foraminifera around Pulau Tioman (Fig. 3). Symbiont-bearing species, such as Calcarina spp., correlated well with the increase in the dissolved oxygen concentration, salinity, and $\mathrm{pH}$. Previously, Prazeres et al. ${ }^{26}$ suggested the need for calibration of the FI for the Indo-west Pacific where Calcarinidae occur. This is because Calcarina spp. usually thrive even in mesothrophic reefs ${ }^{20}$. Despite this concern, our study indicated that not only Calcarina spp. exhibits a good correlation with the water quality. Their relative abundance was significantly higher $(>15 \%)$ in Salang Bay, an area adjacent to where Shahbudin et al. ${ }^{3}$ reported the highest percentages of live coral coverage. Therefore, based on the species-environment relationship assessment, we speculate that calibration of the FI was not necessary for our study area.

Ecological interpretation of FORAM index. The increase in construction and land reclamation activities around the east coast region has exposed many coral reef areas to high rates of sedimentation and a consequent reduction of the diversity of live corals including those in Pulau Tioman ${ }^{3}$. Additionally, active tourism related activities, such as trampling by divers or snorkelers and resuspension of sediment by boats has increased the mortality rate of $\operatorname{corals}^{27,28}$.

A majority of the FI values obtained in the waters around Pulau Tioman were greater than 4, which indicate that the water quality is favorable for reef growth and recovery ${ }^{8,14}$. Despite the excellent performance of the FI in numerous studies ${ }^{8,16,29,30}$, Prazeres et al. ${ }^{26}$ have raised some concerns on the application of this index in new study areas. Therefore, to address this concern and reduce the bias associated with the application of the FI index, we performed PCA. Based on the PCA results (Fig. 2), the FI values in this study showed a positive correlation with good water qualities and a negative correlation with organic matter enrichment. Additionally, the FI values observed in east Pulau Tioman were $>5$, which were higher than those observed in the west. This study, therefore, indicates that the reefs in east Pulau Tioman are more likely to survive and recover from future bleaching events 
compared to those on the west. Our finding are comparable to the study by Shahbudin et al. ${ }^{3}$, which reported that coral coverage in east Pulau Tioman was better than that in the west, where a higher percentage of dead corals was observed. The degraded reef conditions along the west coast of Pulau Tioman has been associated with rapid coastal development ${ }^{31}$, active tourism ${ }^{32}$, and boating activities ${ }^{3}$.

Three stations (i.e., E3, F1, and G1) that recorded lower FI values $(\mathrm{FI}<4)$ in this study are famous diving and snorkeling sites, and their reef conditions are similar to those established by Shahbudin et al. ${ }^{3}$ and Akmal et al. ${ }^{33}$. These three stations are located near the jetty of the Pulau Tioman Marine Park, which also serves as the route for boat journeys to tourist spots for snorkeling and SCUBA diving activities. These relatively higher anthropogenic activities have led to an increase in the organic matter and nutrient concentrations in the water, which have created a less favorable environment for symbiont-bearing foraminifera and allowed stress-tolerant taxa to dominate 8,11 .

To understand the similarity of the foraminifera assemblages around Pulau Tioman, a Q-mode cluster analysis was conducted. The results indicated that the benthic foraminifera assemblages can be classified into four major groups (i.e., Group A, Group B, Group C, and Group D) (Fig. 4). Three of these groups (Group A, Group B, and Group C) represent foraminifera assemblages found on the western side of the island. Group A represents deep water conditions dominated by Numulites venosus and Operculina ammonoides. Both symbiont-bearing species that belong to the Nummulitidae family have been reported to have better growth rates in regions with low light ${ }^{34}$, thereby explaining their increase in abundance at the deeper reef slope area ( $>18 \mathrm{~m}$ water depth) in west Pulau Tioman. The calculated FI for Group A $(\mathrm{FI}>6)$ shows that the water quality conditions within these stations (F3 and G3) can be classified as oligotrophic, which is optimal for reef recovery ${ }^{11,26}$. Hence, despite the intensity of diving activity in Mesoh and Panuba Bay, the increased distance from the shoreline has reduced the anthropogenic impacts on coral reefs and supported healthy coral growth and recovery ${ }^{35}$. Meanwhile, Group B recorded a significant increase in the porcelaneous foraminifera group, with a higher abundance of stress-tolerant taxa, such as Ammonia tepida. In west Pulau Tioman, the high average composition of organic matter (3.81\%) in the sediment serves as a food source for heterotrophic taxa and increases the number of stress tolerant species, such as Ammonia. The FI values for this group varied between 2.7 and 4.0, with the lowest values recorded in the vicinity of Mesoh, where high snorkeling and diving activities occur. The sheltered beach in Mesoh is among the most popular sites for locals and tourists to enjoy swimming and snorkeling. Based on the observations during field sampling, the water in F1 (Mesoh) is more turbid with numerous coral fragments present close to the shoreline. Group C represents foraminifera assemblages that are distributed in shallow waters (6-7 $\mathrm{m}$ depth) in west Pulau Tioman. This group has a relatively lower quantity of stress-tolerant taxa $(<5 \%)$, but a relatively higher quantity of heterotrophic species, such as Eponides, Discorbinella, and Textularia. The presence of abundant sources of food may have promoted the increase in the number of heterotrophic taxa but they are limited by the dominance of stress-tolerant taxa ${ }^{11,13}$. Finally, group D represents most of the stations located in east Pulau Tioman with an FI of 6-9, indicating good water conditions for reef growth and recovery. The reduced coastal development activities observed in east Pulau Tioman may have decreased the impact of sedimentation and allowed a greater diversity of live corals to thrive ${ }^{3}$.

This study indicates that the FI is an excellent low-cost monitoring tool that can aid in assessments of water quality surrounding coral reefs. This finding also implies that the FI can be used together with the coral reef health index to determine the conditions and status of coral reefs in the region. Similarly, these indices can be applied to other coral reef ecosystems around Malaysia to determine their health. The range of FI values reported here shows that most of the sampling sites around Pulau Tioman are conducive to coral reef growth and recovery after exposure to any future bleaching events or temporary damages to the ecosystem. Several sites (e.g., Mesoh and Tekek bays) with reduced FI values may not provide optimum conditions for reef recovery. Hence, marine park managers must closely monitor these touristic sites to prevent further coral reef deterioration. The carrying capacity of this ecosystem with respect to visitors and tourists at the Tioman Marine Park should be reviewed to determine optimum conditions for coral reef health, as indicated by the FI results.

\section{Methods}

Study site. The study was conducted at Pulau Tioman, Pahang, Malaysia (Fig. 5). Pulau Tioman is a tropical island situated in the southern South China Sea (SSCS) and is surrounded by extensive coral coverage, which hosts various marine species ${ }^{36}$. The island is influenced by two monsoonal systems: the northeast (NovemberMarch) and southwest monsoons (April-August) ${ }^{37}$. The maximum wave height during the northeast monsoon is $\sim 4 \mathrm{~m}$ while during the southwest monsoon the height is $<1 \mathrm{~m}^{38,39}$. Pulau Tioman is surrounded by numerous coral reefs, with approximately 57-59 genera of hard corals distributed around the island ${ }^{3}$. Acropora, Montipora, and Porites are among the most common coral genera present around Pulau Tioman ${ }^{3,27}$. The extensive reef ecosystem surrounding Pulau Tioman is among the reasons why this island has been established as a National Marine Park by the Malaysian government ${ }^{40}$. The beauty of the island has attracted tourism-related activities since $1990^{41}$. The sheltered west coast of Pulau Tioman (Fig. 5) has become a suitable site for snorkeling and diving activities, as compared with the east side of the island. Therefore, the west coast of Pulau Tioman receives more tourists and is substantially more developed, with numerous resorts and housing areas distributed along the coast ${ }^{3}$. Tourist and recreational diving activities and coastal development may pose a threat to the surrounding reef ecosystem by reducing its resilience to climate change ${ }^{6}$. Therefore, the most viable management approach in the face of climate change is to reduce and monitor local stressors, such as coastal pollution ${ }^{4,42}$. 


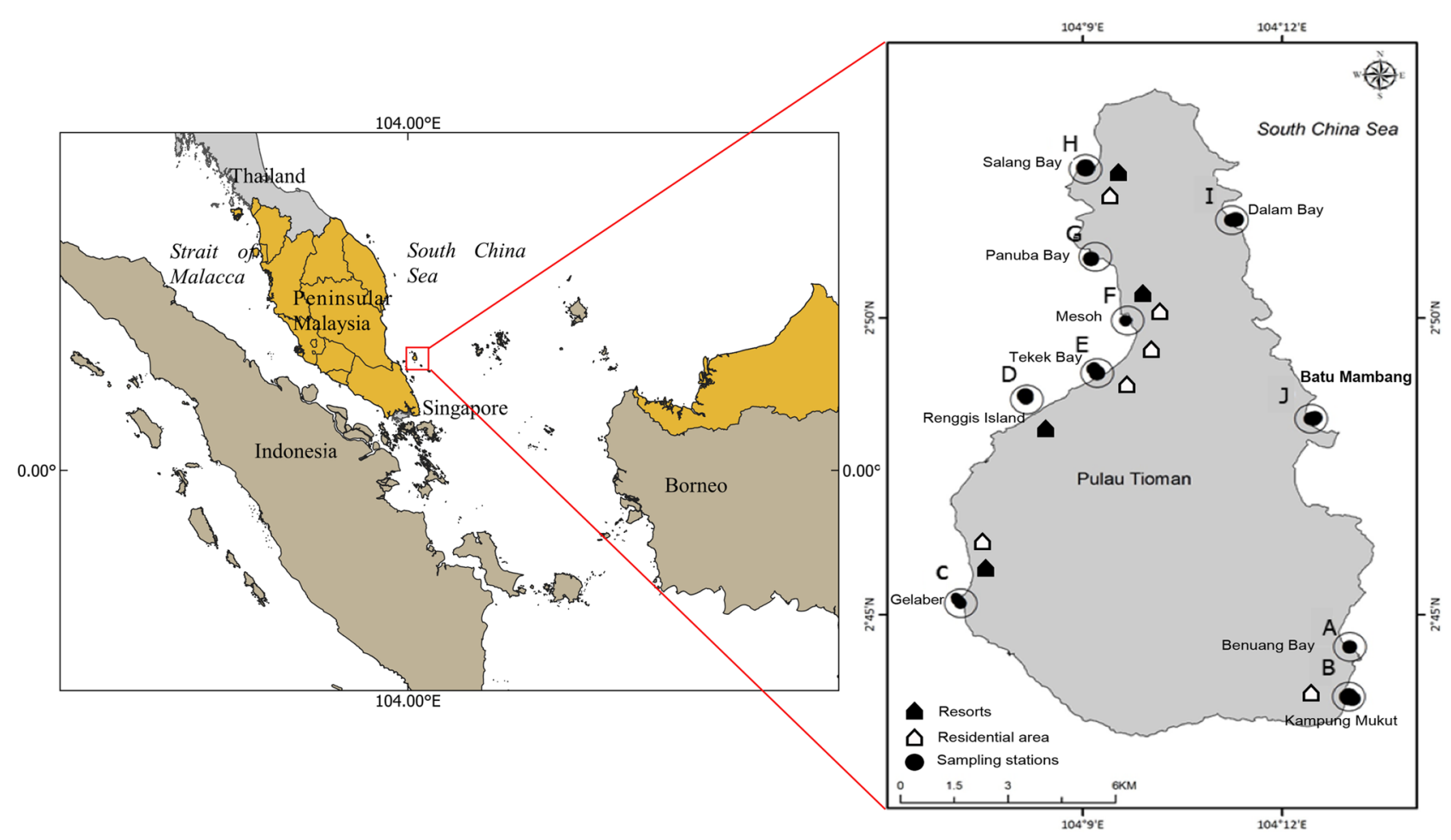

Figure 5. The study area shows (A) the map of Peninsular Malaysia with a box marking Tioman Marine Park. (B) The distribution of sampling stations, resorts, and residential areas on the east and west coast of Pulau Tioman, Malaysia. (Map produce using the Free and Open Source QGIS 3.16.).

Sample collection. To assess the marine environmental health of Pulau Tioman, samples were collected from the coastal waters of the west and east sides of the island. A total of 10 sampling sites were selected based on the intensity of human activities and development along the coast of Pulau Tioman (Fig. 5). A transect of three sampling points was setup at each sampling site for a total of 30 sampling points around Pulau Tioman (Table 4). At each sampling site, three samples were collected along the $100-\mathrm{m}$ transect laid perpendicular to the shore toward the reef slope. Along each transect, one sample was collected at 50-m intervals. Bulk sediment samples were collected by SCUBA divers using a scoop, which were stored in labelled plastic bags. Parameters, such as the water salinity (PSU), temperature $\left({ }^{\circ} \mathrm{C}\right), \mathrm{pH}$, and water depth $(\mathrm{m})$, were obtained in situ at each sampling station using a Hydrolab Quanta Multiparameter operated from a small vessel. All of the collected samples were transported to the Pulau Tioman marine park station in Mesoh for sorting. Sediment samples were divided into two components for foraminiferal and sedimentological analyses. Approximately $30 \mathrm{~cm}^{3}$ of sediments were subsampled from the bulk samples for foraminiferal analysis and were fixed with $4 \%$ buffered formalin ${ }^{43}$. The remaining sediment samples were stored in zip-lock plastic bags, labelled, and brought back to the Central Laboratory of Universiti Malaysia Terengganu for sediment grain size analysis.

Laboratory analysis. The sediment samples for foraminiferal analysis were gently washed under running tap water over a $63-\mu \mathrm{m}$ mesh sieve ${ }^{11}$. The residue on the $63-\mu \mathrm{m}$ sieve was carefully transferred into a pre-labelled weighing boat before being dried in the oven at $40-50^{\circ} \mathrm{C}$ overnight. The dried samples were later stored in plastic bags for analysis. Foraminiferal specimens were handpicked using a fine brush under a stereomicroscope. A total of 300 optimally preserved foraminifera tests were picked from every station ${ }^{24}$. If the samples contained less than 300 foraminifera, all of the specimens were picked ${ }^{24}$. Then, the specimens were sorted and mounted on micropaleontological cardboard slides. Foraminifera identification was performed based on the methods reported in Loeblich \& Tappan $^{44}$ and other regional taxonomic manuscripts ${ }^{24,45,46}$.

The grain size analysis was conducted based on the dry-sieving method by Folk ${ }^{47}$. Approximately $100 \mathrm{~g}$ of dried sediment samples were sieved using a sieve set containing 4000-, 2000-, 1000-, 500-, 250-, 125-, and $63-\mu \mathrm{m}$ sieves and the percentage of each sediment size fraction was determined. The organic matter content in the sediments was determined using the loss on ignition (LOI) method ${ }^{48}$. Prior to heating, $5 \mathrm{~g}$ of each sediment sample was weighed. The samples were gradually heated until they reached $500-550{ }^{\circ} \mathrm{C}$, followed by ignition for $4 \mathrm{~h}$, cooled to room temperature $\left(30^{\circ} \mathrm{C}\right)$, and the final weight was recorded. The percentages of organic matter were calculated based on the formula provided in Heiri et al. ${ }^{49}$. 


\begin{tabular}{|c|c|c|c|}
\hline \multirow[b]{2}{*}{ Description of locations } & \multirow[b]{2}{*}{ Station } & \multicolumn{2}{|l|}{ Coordinate } \\
\hline & & Longitude & Latitude \\
\hline \multirow{3}{*}{$\begin{array}{l}\text { Benuang } \\
\text { Low number of snorkelling and SCUBA diving activity }\end{array}$} & $\mathrm{A} 1$ & $2^{\circ} 44^{\prime} 27.4^{\prime \prime} \mathrm{N}$ & $104^{\circ} 13^{\prime} 01.3^{\prime \prime} \mathrm{E}$ \\
\hline & A2 & $2^{\circ} 42^{\prime} 27.7^{\prime \prime} \mathrm{N}$ & $104^{\circ} 13^{\prime} 04.9^{\prime \prime} \mathrm{E}$ \\
\hline & $\mathrm{A} 3$ & $2^{\circ} 42^{\prime} 28.9^{\prime \prime} \mathrm{N}$ & $104^{\circ} 13^{\prime} 06.3^{\prime \prime} \mathrm{E}$ \\
\hline \multirow{3}{*}{$\begin{array}{l}\text { Kampung Mukut } \\
\text { Fisherman village, not a snorkelling and SCUBA diving site }\end{array}$} & B1 & $2^{\circ} 43^{\prime} 37.4^{\prime \prime} \mathrm{N}$ & $104^{\circ} 13^{\prime} 00.3^{\prime \prime} \mathrm{E}$ \\
\hline & B2 & $2^{\circ} 43^{\prime} 36.2^{\prime \prime} \mathrm{N}$ & $104^{\circ} 13^{\prime} 01.9^{\prime \prime} \mathrm{E}$ \\
\hline & B3 & $2^{\circ} 43^{\prime} 35.2^{\prime \prime} \mathrm{N}$ & $104^{\circ} 13^{\prime} 03.5^{\prime \prime} \mathrm{E}$ \\
\hline \multirow{3}{*}{$\begin{array}{l}\text { Gelaber } \\
\text { Not a snorkelling and SCUBA diving site }\end{array}$} & $\mathrm{C} 1$ & $2^{\circ} 45^{\prime} 11.6^{\prime \prime} \mathrm{N}$ & $104^{\circ} 07^{\prime} 09.7^{\prime \prime} \mathrm{E}$ \\
\hline & $\mathrm{C} 2$ & $2^{\circ} 45^{\prime} 15.5^{\prime \prime} \mathrm{N}$ & $104^{\circ} 07^{\prime} 07.1^{\prime \prime} \mathrm{E}$ \\
\hline & $\mathrm{C} 3$ & $2^{\circ} 45^{\prime} 17.7^{\prime \prime} \mathrm{N}$ & $104^{\circ} 07^{\prime} 05.2^{\prime \prime} \mathrm{E}$ \\
\hline \multirow{3}{*}{$\begin{array}{l}\text { Renggis Island } \\
\text { High number of snorkelling and SCUBA diving activities at this site }\end{array}$} & D1 & $2^{\circ} 48^{\prime} 37.4^{\prime \prime} \mathrm{N}$ & $104^{\circ} 08^{\prime} 09.6^{\prime \prime} \mathrm{E}$ \\
\hline & D2 & $2^{\circ} 48^{\prime} 39.0^{\prime \prime} \mathrm{N}$ & $104^{\circ} 08^{\prime} 08.8^{\prime \prime} \mathrm{E}$ \\
\hline & D3 & $2^{\circ} 48^{\prime} 41.6^{\prime \prime} \mathrm{N}$ & $104^{\circ} 08^{\prime} 08.3^{\prime \prime} \mathrm{E}$ \\
\hline \multirow{3}{*}{$\begin{array}{l}\text { Tekek Bay } \\
\text { Snorkelling and SCUBA diving site, boating route, Jetty }\end{array}$} & E1 & $2^{\circ} 49^{\prime} 04.4^{\prime \prime} \mathrm{N}$ & $104^{\circ} 09^{\prime} 13.2^{\prime \prime} \mathrm{E}$ \\
\hline & E2 & $2^{\circ} 49^{\prime} 08.2^{\prime \prime} \mathrm{N}$ & $104^{\circ} 09^{\prime} 10.4^{\prime \prime} \mathrm{E}$ \\
\hline & E3 & $2^{\circ} 49^{\prime} 11.5^{\prime \prime} \mathrm{N}$ & $104^{\circ} 09^{\prime} 08.2^{\prime \prime} \mathrm{E}$ \\
\hline \multirow{3}{*}{$\begin{array}{l}\text { Mesoh } \\
\text { Marine Park Centre, Jetty, snorkelling and SCUBA diving site }\end{array}$} & F1 & $2^{\circ} 49^{\prime} 57.9^{\prime \prime} \mathrm{N}$ & $104^{\circ} 09^{\prime} 42.4^{\prime \prime} \mathrm{E}$ \\
\hline & F2 & $2^{\circ} 49^{\prime} 57.4^{\prime \prime} \mathrm{N}$ & $104^{\circ} 09^{\prime} 40.7^{\prime \prime} \mathrm{E}$ \\
\hline & F3 & $2^{\circ} 49^{\prime} 57.1^{\prime \prime} \mathrm{N}$ & $104^{\circ} 09^{\prime} 38.7^{\prime \prime} \mathrm{E}$ \\
\hline \multirow{3}{*}{$\begin{array}{l}\text { Panuba Bay } \\
\text { Snorkelling and SCUBA diving site, boating route }\end{array}$} & G1 & $2^{\circ} 51^{\prime} 01.9^{\prime \prime} \mathrm{N}$ & $104^{\circ} 09^{\prime} 11.4^{\prime \prime} \mathrm{E}$ \\
\hline & G2 & $2^{\circ} 51^{\prime} 00.8^{\prime \prime} \mathrm{N}$ & $104^{\circ} 09^{\prime} 09.4^{\prime \prime} \mathrm{E}$ \\
\hline & G3 & $2^{\circ} 50^{\prime} 59.6^{\prime \prime} \mathrm{N}$ & $104^{\circ} 09^{\prime} 07.5^{\prime \prime} \mathrm{E}$ \\
\hline \multirow{3}{*}{$\begin{array}{l}\text { Salang Bay } \\
\text { Not a snorkelling and SCUBA diving site }\end{array}$} & $\mathrm{H} 1$ & $2^{\circ} 52^{\prime} 30.4^{\prime \prime} \mathrm{N}$ & $104^{\circ} 09^{\prime} 02.6^{\prime \prime} \mathrm{E}$ \\
\hline & $\mathrm{H} 2$ & $2^{\circ} 52^{\prime} 31.9^{\prime \prime} \mathrm{N}$ & $104^{\circ} 09^{\prime} 02.5^{\prime \prime} \mathrm{E}$ \\
\hline & $\mathrm{H} 3$ & $2^{\circ} 52^{\prime} 33.5^{\prime \prime} \mathrm{N}$ & $104^{\circ} 09^{\prime} 02.7^{\prime \prime} \mathrm{E}$ \\
\hline \multirow{3}{*}{$\begin{array}{l}\text { Dalam Bay } \\
\text { Not a snorkelling and SCUBA diving site }\end{array}$} & 11 & $2^{\circ} 51^{\prime} 38.8^{\prime \prime} \mathrm{N}$ & $104^{\circ} 11^{\prime} 14.5^{\prime \prime} \mathrm{E}$ \\
\hline & $\mathrm{I} 2$ & $2^{\circ} 51^{\prime} 38.9^{\prime \prime} \mathrm{N}$ & $104^{\circ} 11^{\prime} 16.8^{\prime \prime} \mathrm{E}$ \\
\hline & $\mathrm{I} 3$ & $2^{\circ} 51^{\prime} 39.5^{\prime \prime} \mathrm{N}$ & $104^{\circ} 11^{\prime} 18.2^{\prime \prime} \mathrm{E}$ \\
\hline \multirow{3}{*}{$\begin{array}{l}\text { Batu Mambang } \\
\text { Not a snorkelling and SCUBA diving site }\end{array}$} & $\mathrm{J} 1$ & $2^{\circ} 48^{\prime} 18.1^{\prime \prime} \mathrm{N}$ & $104^{\circ} 12^{\prime} 26.2^{\prime \prime} \mathrm{E}$ \\
\hline & $\mathrm{J} 2$ & $2^{\circ} 48^{\prime} 18.1^{\prime \prime} \mathrm{N}$ & $104^{\circ} 12^{\prime} 28.3^{\prime \prime} \mathrm{E}$ \\
\hline & $\mathrm{J} 3$ & $2^{\circ} 48^{\prime} 19.1^{\prime \prime} \mathrm{N}$ & $104^{\circ} 12^{\prime} 30.1^{\prime \prime} \mathrm{E}$ \\
\hline
\end{tabular}

Table 4. Brief description and coordinate of all 30 sampling stations around the coastal waters of Pulau Tioman. All location names are written in bold in the description column.

Data and statistical analyses. To avoid using reworked samples, only foraminiferal species with a relative abundance of more than $2 \%$ were maintained for further statistical analysis. Indices, such as Fisher's alpha diversity index (a), Shannon-Wiener species diversity $\left(\mathrm{H}^{\prime}\right)$, and species evenness of Pielou ( $\left.\mathrm{J}^{\prime}\right)$, were analyzed using the PAST (PAleontological STatistics) software version 3. Cluster analysis was performed to simplify the large datasets for easy recognition ${ }^{50}$. The Principal Component Analysis (PCA) was performed to investigate the relationships between the FI values and the sediment and water quality around Pulau Tioman. In addition, to investigate the relationships between the foraminifera species and the environment, canonical correspondence analysis (CCA) with a Monte Carlo permutation test was performed ${ }^{51}$. Foraminifera species with a relative abundance of $>10 \%$ in at least one sample were selected for the CCA and permutation test.

FORAM index. The FI was used to determine the health status of the reef at Pulau Tioman. The foraminifera species collected around Pulau Tioman were identified and segregated into functional groups (Table 5), as suggested by Hallock et al. ${ }^{11}$ and Carnahan et al. ${ }^{29}$. The calculation of the FI was based on the equation proposed by Hallock et al. ${ }^{11}$. The values obtained from the calculation were interpreted based on Table 2 . 


\begin{tabular}{|c|c|c|c|c|}
\hline Functional group & Order & Family & Genus & Distribution \\
\hline \multirow{11}{*}{ Symbiont-bearing } & \multirow{4}{*}{ Rotaliida } & Amphisteginidae & Amphistegina & Circumtropical \\
\hline & & Calcarinidae & 5 genera & Indo-Pacific \\
\hline & & \multirow{2}{*}{ Nummulitidae } & Heterostegina & Circumtropical \\
\hline & & & 3 other genera & Indo-Pacific \\
\hline & \multirow{7}{*}{ Miliolida } & \multirow{2}{*}{ Miliolida } & Alveolinella & Indo-Pacific \\
\hline & & & Borelis & Circumtropical \\
\hline & & Peneroplidae & Several genera & Circumtropical \\
\hline & & \multirow{4}{*}{ Soritidae } & Sorites & Circumtropical \\
\hline & & & Amphisorus & Circumtropical \\
\hline & & & 3 genera & Caribbean \\
\hline & & & Marginopora & Indo-Pacific \\
\hline \multirow{6}{*}{ Opportunistic ${ }^{\star}$ (stress-tolerant) } & Trochamminida & Trochamminidae & Several genera & Cosmopolitan \\
\hline & Textulariida & Lituolidae & Several genera & Cosmopolitan \\
\hline & \multirow{2}{*}{ Buliminida } & Bolivinidae & Several genera & Cosmopolitan \\
\hline & & Buliminidae & Several genera & Cosmopolitan \\
\hline & \multirow{2}{*}{ Rotaliida } & Rotaliidae & Ammonia & Cosmopolitan \\
\hline & & Elphidiidae & Elphidium & Cosmopolitan \\
\hline \multirow{4}{*}{ Other (Heterotrophic) Small Taxa } & Miliolida & \multicolumn{2}{|l|}{ Most except larger taxa noted above } & Cosmopolitan \\
\hline & Rotaliida & \multicolumn{2}{|l|}{ Most except those noted above } & Cosmopolitan \\
\hline & Textulariida & \multicolumn{2}{|l|}{ Most } & Cosmopolitan \\
\hline & Other & \multicolumn{2}{|l|}{ Most } & Cosmopolitan \\
\hline
\end{tabular}

Table 5. Functional Groups assigned to benthic foraminifera used in coral reef assessment ${ }^{11,29}$. ${ }^{\star}$ Full range of opportunistic genera under local conditions is not well known.

\section{Data availability}

All data generated or analyzed during this study are included in this article (and its Supplementary Information files).

Received: 13 November 2020; Accepted: 8 April 2021

Published online: 26 April 2021

\section{References}

1. Hoegh-Guldberg, O. Climate change, coral bleaching and the future of the world's coral reefs. Mar. Freshwater Res. 50(8), 839-866. https://doi.org/10.1071/MF99078 (1999).

2. Moberg, F. \& Folke, C. Ecological goods and services of coral reef ecosystems. Ecol. Econ. 29(2), 215-233. https://doi.org/10.1016/ S0921-8009(99)00009-9 (1999).

3. Shahbudin, S., Fikri Akmal, K. F., Faris, S., Normawaty, M. N. \& Mukai, Y. Current status of coral reefs in Tioman Island Peninsular Malaysia. Turk. J. Zool. 41(2), 294-305. https://doi.org/10.3906/zoo-1511-42 (2017).

4. Anthony, K. R. N. et al. Operationalizing resilience for adaptive coral reef management under global environmental change. Glob. Change Biol. 21(1), 48-61. https://doi.org/10.1111/gcb.12700,Pubmed:25196132 (2015).

5. Bruno, J. F. \& Selig, E. R. Regional decline of coral cover in the Indo-Pacific: timing, extent, and subregional comparisons. PLoS ONE 2(8), e711. https://doi.org/10.1371/journal.pone.0000711,Pubmed:17684557 (2007).

6. Cowburn, B., Samoilys, M. A. \& Obura, D. The current status of coral reefs and their vulnerability to climate change and multiple human stresses in the Comoros Archipelago Western Indian Ocean. Mar. Pollut. Bull. 133, 956-969. https://doi.org/10.1016/j. marpolbul.2018.04.065,Pubmed:29778407 (2018).

7. Schueth, J. D. \& Frank, T. D. Reef foraminifera as bioindicators of coral reef health: Low Isles Reef, northern Great Barrier Reef Australia. J. Foram. Res. 38(1), 11-22. https://doi.org/10.2113/gsjfr.38.1.11 (2008).

8. Uthicke, S., Thompson, A. \& Schaffelke, B. Effectiveness of benthic foraminiferal and coral assemblages as water quality indicators on inshore reefs of the Great Barrier Reef Australia. Coral Reefs 29(1), 209-225. https://doi.org/10.1007/s00338-009-0574-9 (2010).

9. Natsir, S. M. \& Subkhan, M. The distribution of benthic foraminifera in coral reefs community and seagrass bad of Belitung Islands based on FORAM Index. J. Coast. Dev. 15(1), 51-58 (2012).

10. Alve, E. Benthic foraminiferal responses to estuarine pollution: a review. J. Foram. Res. 25(3), 190-203. https://doi.org/10.2113/ gsjfr.25.3.190 (1995).

11. Hallock, P., Lidz, B. H., Cockey-Burkhard, E. M. \& Donnelly, K. B. Foraminifera as bioindicators in coral reef assessment and monitoring: the FORAM index. Foraminifera in reef assessment and monitoring. Environ. Monit. Assess. 81(1-3), 221-238 (2003).

12. Sen Gupta, B. K. Systematics of modern Foraminifera. In Sen Gupta, B.K. (ed.) Modern Foraminifera (Springer, 2003) 7-36. https:// doi.org/10.1007/0-306-48104-9.

13. Carnahan, E. A. Foraminiferal Assemblages as Bioindicators of Potentially Toxic Elements in Biscayne Bay, Florida. M.Sc. thesis (U.S.A.: University of South Florida, 2005)

14. Barbosa, C. F., Prazeres, M. D. F., Ferreira, B. P. \& Seoane, J. C. S. Foraminiferal assemblage and Reef Check census in coral reef health monitoring of East Brazilian margin. Mar. Micropaleontol. 73(1-2), 62-69. https://doi.org/10.1016/j.marmicro.2009.07.002 (2009).

15. Dimiza, M. D., Koukousioura, O., Triantaphyllou, M. V. \& Dermitzakis, M. D. Live and dead benthic foraminiferal assemblages from coastal environments of the Aegean Sea (Greece): distribution and diversity. Rev. Micropaleontol. 59(1), 19-32. https://doi. org/10.1016/j.revmic.2015.10.002 (2016). 
16. Uthicke, S. \& Nobes, K. Benthic foraminifera as ecological indicators for water quality on the Great Barrier Reef. Estuarine Coast. Shelf Sci. 78(4), 763-773. https://doi.org/10.1016/j.ecss.2008.02.014 (2008).

17. Renema, W. Terrestrial influence as a key driver of spatial variability in large benthic foraminiferal assemblage composition in the Central Indo-Pacific. Earth Sci. Rev. 177, 514-544. https://doi.org/10.1016/j.earscirev.2017.12.013 (2018).

18. Förderer, M. \& Langer, M. R. Exceptionally species-rich assemblages of modern larger benthic foraminifera from nearshore reefs in northern Palawan (Philippines). Rev. Micropaleontol. 100, 65. https://doi.org/10.1016/j.revmic.2019.100387 (2019).

19. Eichler, P. P. B. \& de Moura, D. S. Symbiont-bearing foraminifera as health proxy in coral reefs in the equatorial margin of Brazil. Environ. Sci. Pollut. Res. 27(12), 13637-13661. https://doi.org/10.1007/s11356-019-07483-y,Pubmed:32034594 (2020).

20. Renema, W. Is increased calcarinid (foraminifera) abundance indicating a larger role for macro-algae in Indonesian Plio-Pleistocene coral reefs?. Coral Reefs 29(1), 165-173. https://doi.org/10.1007/s00338-009-0568-7 (2010).

21. Chen, C. \& Lin, H. L. Applying benthic Foraminiferal assemblage to evaluate the coral reef condition in Dongsha Atoll lagoon. Zool. Stud. 56, e20. https://doi.org/10.6620/ZS.2017.56-20,Pubmed:31966219 (2017).

22. Hallock, P. Interoceanic differences in foraminifera with symbiotic algae: a result of nutrient supplies. Mar. Sci. Faculty Publication 1228 (1988). https://scholarcommons.usf.edu/msc_facpub/1228

23. Langer, M. R., Weinmann, A. E., Lötters, S., Bernhard, J. M. \& Rödder, D. Climate-driven range extension of Amphistegina (protista, foraminiferida): Models of current and predicted future ranges [Protista, Foraminiferida]. PLoS ONE 8(2), e54443. https:// doi.org/10.1371/journal.pone.0054443,Pubmed:23405081 (2013).

24. Culver, S. J. et al. Distribution of foraminifera of the Poverty continental margin, New Zealand: implications for sediment transport. J. Foram. Res. 42(4), 305-326. https://doi.org/10.2113/gsjfr.42.4.305 (2012).

25. Szarek, R. Biodiversity and Biogeography of Recent Benthic Foraminiferal Assemblages in the South Western South China Sea (Sunda Shelf). Doctoral dissertation (Kiel, Kiel, Germany: Christian-Albrechts Universität, 2001).

26. Prazeres, M., Martínez-Colón, M. \& Hallock, P. Foraminifera as bioindicators of water quality: the FoRAM Index revisited. Environ. Pollut. 257, 113612. https://doi.org/10.1016/j.envpol.2019.113612,Pubmed:31784269 (2020).

27. Toda, T. et al. Community structures of coral reefs around Peninsular Malaysia. J. Oceanogr. 63(1), 113-123. https://doi.org/10. 1007/s10872-007-0009-6 (2007).

28. Zakai, D. \& Chadwick-Furman, N. E. Impacts of intensive recreational diving on reef corals at Eilat, northern Red Sea. Biol. Conserv. 105(2), 179-187. https://doi.org/10.1016/S0006-3207(01)00181-1 (2002).

29. Carnahan, E. A., Hoare, A. M., Hallock, P., Lidz, B. H. \& Reich, C. D. Foraminiferal assemblages in Biscayne Bay, Florida, USA: responses to urban and agricultural influence in a subtropical estuary. Mar. Pollut. Bull. 59(8-12), 221-233. https://doi.org/10. 1016/j.marpolbul.2009.08.008 (2009).

30. Oliver, L. M. et al. Contrasting responses of coral reef fauna and foraminiferal assemblages to human influence in la Parguera Puerto Rico. Mar. Environ. Res. 99, 95-105. https://doi.org/10.1016/j.marenvres.2014.04.005 (2014).

31. Unsworth, R. K., Clifton, J. \& Smith, D. J. Marine Research and Conservation in the Coral Triangle: The Wakatobi National Park (Nova Science Publishers, 2010).

32. Praveena, S. M., Siraj, S. S. \& Aris, A. Z. Coral reefs studies and threats in Malaysia: a mini review. Rev. Environ. Sci. Bio Technol. 11(1), 27-39. https://doi.org/10.1007/s11157-011-9261-8 (2012).

33. Akmal, K. F., Shahbudin, S., Faiz, M. H. M. \& Hamizan, Y. M. Diversity and abundance of scleractinian corals in the East Coast of peninsular Malaysia: a case study of Redang and Tioman Islands. Ocean Sci. J. 54(3), 435-456. https://doi.org/10.1007/s12601019-0018-6 (2019).

34. Oron, S., Abramovich, S., Almogi-Labin, A., Woeger, J. \& Erez, J. Depth related adaptations in symbiont bearing benthic foraminifera: new insights from a field experiment on Operculina ammonoides. Sci. Rep. 8(1), 9560. https://doi.org/10.1038/s41598-01827838-8,Pubmed:29934603 (2018).

35. Oliver, J. K., Berkelmans, R. \& Eakin, C. M. Coral bleaching in space and time in (eds van Oppen, M. J. H. \& Lough, J. M.) Coral Bleaching. Ecological Studies. 205 (Springer, 2009) 21-39.

36. Harborne, A., Fenner, D., Barnes, A., Beger, M., Harding, S. \& Roxburgh, T. Status Report on the Coral Reefs of the East Coast of Peninsular Malaysia. Report Prepared to Department of Fisheries Malaysia, Kuala Lumpur, Malaysia, 361-369 (2000)

37. Akhir, M., Fadzil, M., Zakaria, N. Z. \& Tangang, F. Intermonsoon variation of physical characteristics and current circulation along the east coast of Peninsular Malaysia. Int. J. Oceanogr., 1-9 (2014)

38. Chu, P. C., Qi, Y., Chen, Y., Shi, P. \& Mao, Q. South China sea wind-wave characteristics. Part I: validation of WAVEWATCH-III using TOPEX/Poseidon data. J. Atmos. Ocean. Technol. 21(11), 1718-1733. https://doi.org/10.1175/JTECH1661.1 (2004).

39. Marghany, M. Velocity bunching model for modelling wave spectra along east coast of Malaysia. J. Indian Soc. Remote Sens. 32(2), 185-198. https://doi.org/10.1007/BF03030875 (2004).

40. Department of Marine Park, Malaysia. Laporan Tahunan Jabatan Taman Laut Malaysia. Annual report (2012)

41. Chia, K. W., Ramachandran, S., Ho, J. A. \& Ng, S. S. I. Conflicts to consensus: Stakeholder perspectives of Tioman Island tourism sustainability. Int. J. Bus. Soc. 19, 159 (2018).

42. Game, E. T., Meijaard, E., Sheil, D. \& McDonald-Madden, E. Conservation in a wicked complex world; challenges and solutions. Conserv. Lett. 7(3), 271-277. https://doi.org/10.1111/conl.12050 (2014).

43. Murray, J. W. Ecology and applications of benthic foraminifera. Cambridge University Press (2006)

44. Loeblich, A. R. \& Tappan, H. Foraminiferal Genera and Their Classification (Van Nostrand Reinhold, 1987).

45. Szarek, R., Kuhnt, W., Kawamura, H. \& Kitazato, H. Distribution of recent benthic foraminifera on the Sunda Shelf (South China Sea). Mar. Micropaleontol. 61(4), 171-195. https://doi.org/10.1016/j.marmicro.2006.06.005 (2006).

46. Martin, S. Q. et al. Announcements. J. Foram. Res. 48(4), 388-389. https://doi.org/10.2113/gsffr.48.4.388 (2018).

47. Folk, R. L. Petrology of Sedimentary Rocks (Hemphill Publishing Company, 1980)

48. Dean, W. E. Determination of carbonate and organic matter in calcareous sediments and sedimentary rocks by loss on ignition; comparison with other methods. J. Sediment. Res. 44(1), 242-248 (1974).

49. Heiri, O., Lotter, A. F. \& Lemcke, G. Loss on ignition as a method for estimating organic and carbonate content in sediments: reproducibility and comparability of results. J. Paleolimnol. 25(1), 101-110. https://doi.org/10.1023/A:1008119611481 (2001).

50. Romesburg, C. Cluster Analysis for Researchers (Lulu Press, 2004).

51. Milker, Y. et al. Distribution of recent benthic foraminifera in shelf carbonate environments of the western Mediterranean Sea. Mar. Micropaleontol. 73(3-4), 207-225. https://doi.org/10.1016/j.marmicro.2009.10.003 (2009).

\section{Acknowledgements}

Authors would like to extend their gratitude to En. Syed Ahmad Rizal Tuan Nik and Syed Shahrul Afzan Syed Bidin for their help in surface sediment samples collection. This study is funded by the grant research from Department of Fisheries Malaysia (DOF) and Joseph A. Cushman Award for Student Research (2019) and supported by Fundamental Research Grant Scheme (FRGS/1/2018/WAB09/UMT/02/3). 


\section{Author contributions}

A.A.N.A. performed foraminifera analysis, statistical analysis, and the calculation of the FORAM index. Has also contributed to writing the manuscript. M.F.I. proposed this study and contributed to major revisions of the manuscript, including statistical interpretations and writing the discussion. P.H-J. contributed to a critical revision of the manuscript with input on the language and flow of the manuscript. S.H., and S.W.N.W. contributed their research funding for field and laboratory activities. A.N., and M.O.A.R.A. participated in field sample collection and laboratory analysis of the sediment and organic matter content. I.M.N. assisted in the field sampling and data collection.

\section{Competing interests}

The authors declare no competing interests.

Additional information

Supplementary Information The online version contains supplementary material available at https://doi.org/ 10.1038/s41598-021-88404-3.

Correspondence and requests for materials should be addressed to F.I.M.

Reprints and permissions information is available at www.nature.com/reprints.

Publisher's note Springer Nature remains neutral with regard to jurisdictional claims in published maps and institutional affiliations.

(c) Open Access This article is licensed under a Creative Commons Attribution 4.0 International License, which permits use, sharing, adaptation, distribution and reproduction in any medium or format, as long as you give appropriate credit to the original author(s) and the source, provide a link to the Creative Commons licence, and indicate if changes were made. The images or other third party material in this article are included in the article's Creative Commons licence, unless indicated otherwise in a credit line to the material. If material is not included in the article's Creative Commons licence and your intended use is not permitted by statutory regulation or exceeds the permitted use, you will need to obtain permission directly from the copyright holder. To view a copy of this licence, visit http://creativecommons.org/licenses/by/4.0/.

(C) The Author(s) 2021 